\title{
Sodium Fluoride Induces Hepato-Renal Oxidative Stress and Pathophysiological Changes in Experimental Animals
}

\author{
Azab Elsayed Azab ${ }^{1 *}$, Mohamed Omer Albasha' ${ }^{2}$, J. M. Jbireal ${ }^{1}$, Almokhtar A. Adwas ${ }^{3}$ \\ ${ }^{1}$ Department of Physiology, Faculty of Medicine, Sabratha University, Sabratha, Libya \\ ${ }^{2}$ Department of Zoology, Faculty of Science, Alejelat, Zawia University, Alejelat, Libya \\ ${ }^{3}$ Department of Pharmacology, Faculty of Medicine, Sabratha University, Sabratha, Libya \\ Email: *azabelsaied@yahoo.com
}

How to cite this paper: Azab, A.E., Albasha, M.O., Jbireal, J.M. and Adwas, A.A. (2018) Sodium Fluoride Induces Hepato-Renal Oxidative Stress and Pathophysiological Changes in Experimental Animals. Open Journal of Apoptosis, 7, 1-23.

https://doi.org/10.4236/ojapo.2018.71001

Received: January 10, 2018

Accepted: January 28, 2018

Published: January 31, 2018

Copyright () 2018 by authors and Scientific Research Publishing Inc. This work is licensed under the Creative Commons Attribution International License (CC BY 4.0).

http://creativecommons.org/licenses/by/4.0/

(c) (†) Open Access

\begin{abstract}
The liver is a primary site for xenobiotics detoxification, and its metabolism is readily altered by toxicity. The kidney is a common target for toxic xenobiotics due to its capacity to extract and concentrate toxic substances by highly specialized cells. So, they are the target organs of sodium fluoride toxicity. The aim of this review is to highlight on hepatorenal oxidative stress and pathophysiological changes induced by treatment of experimental animals with sodium fluoride. Our review shows fluoride toxicosis caused an elevation in the serum activities of alanine aminotransferase, aspartate aminotransferase, alkaline phosphatase, lactate dehydrogenase, acid phosphatase, and the level of total bilirubin, and reduction in the serum levels of total protein, albumin, and globulins, and serious histopathological changes in the hepaic tissues. Also, $\mathrm{NaF}$ administration caused increases in serum urea, creatinine, uric acid, sodium ions, and chloride ions levels and serious histopathological changes in the kidney tissues. Treatment of experimental animals with $\mathrm{NaF}$ induced oxidative stress in hepatic and renal tissues. It can be concluded that administration of sodium fluoride to experimental animals induced oxidative stress, serious hepatorenal histopathological changes, and disturbance in liver and kidney functions. So, human should be advised to decrease exposure to sodium fluoride to decrease the harmful effects of $\mathrm{NaF}$ on liver and kidney.
\end{abstract}

\section{Keywords}

Sodium Fluoride Toxicity, Oxidative Stress, Hepatorenal Histopathological Changes, Hepatorenal Pathophysiological Changes 


\section{Introduction}

The liver is the principal organ responsible for metabolism and involved in the metabolism of toxic compounds produced during systemic processes and exogenous toxins entering into the organisms from the environment [1] [2]. The liver is a primary site for xenobiotics detoxification, and its metabolism is readily altered by toxicity. The xenobiotic hepatotoxic action is usually expressed by cell respiration disorders that interfere with oxidation and reduction mechanisms, either through impairment in protein, carbohydrate, and lipid metabolism or by disturbances in intra- and extracellular transport. Consequently, whole cell or its cytoplasmic organelles can be damaged [3]. The kidney is a common target for toxic xenobiotics due to its capacity to extract and concentrate toxic substances by highly specialized cells and also, due to its large blood flow (about $21 \%$ of cardiac output) [4] [5].

Fluoride is a well-determined non-biodegradable and moderate pollutant, which at high levels causes serious health problems [2]. The liver is the target organ of sodium fluoride $(\mathrm{NaF})$ toxicity [6]. It was assumed that $\mathrm{NaF}$ would induce both pathomorphological and metabolic changes in the liver [2] [7]. Fluorides are released into the environment due to human activities and naturally from natural sources. The manufacturing of steel, brick, ceramic, glass, aluminum, copper, nickel, glues, adhesives, and the production of hydrogen fluoride, chlorofluorocarbon and phosphate fertilizer and use of fertilizer released fluoride into the environment (air, water, plants, animals, rocks, and soil) [8] [9] [10] [11] [12]. Combustion of fluoride impurities containing coals as well as the use of fluoride-containing pesticides and controlled fluoridation of drinking water supplies also release fluoride into the environment [12] [13]. Mining activities and deep wells of springs may release a large amount of fluoride into the atmosphere. Fluorides also released into the environment naturally through weathering and dissolution of fluoride-bearing minerals like fluorite, rock phosphate, fluorapatites, and topaz [9] [12] [14]. Fluoride releases into the environment through atmospheric emissions from volcanoes and seawater [12] [13]. Traces of fluorides are present in many waters; higher concentrations are often associated with underground sources. In seawater, a total fluoride concentration of $1.3 \mathrm{mg} /$ liter has been reported [15]. In areas rich in fluoride-containing minerals, well water may contain up to about $10 \mathrm{mg}$ of fluoride per liter. Fluorides may also enter a river as a result of industrial discharges [15]. In groundwater, fluoride concentrations vary with the type of rock the water flows through but do not usually exceed $10 \mathrm{mg} /$ liter [16]. All vegetation contains some fluoride, which is absorbed from soil and water. The highest levels in field-grown vegetables are found in curly kale (up to $40 \mathrm{mg} / \mathrm{kg}$ fresh weight) and endive (0.3 - 2.8 $\mathrm{mg} / \mathrm{kg}$ fresh weight) [15]. Other foods containing high levels include fish (0.1 $30 \mathrm{mg} / \mathrm{kg}$ ) and tea [15] [16] [17]. High concentrations of tea can be caused by high natural concentrations in tea plants or by the use of additives during growth or fermentation. Levels in dry tea can be $3-300 \mathrm{mg} / \mathrm{kg}$ (average 100 $\mathrm{mg} / \mathrm{kg}$ ), so 2 - 3 cups of tea contain approximately $0.4-0.8 \mathrm{mg}$ [15] [17] [18]. In 
areas where water with high fluoride content is used to prepare tea, the intake via tea can be several times greater [17]. So, the consumption of tea is a major risk factor for kidney disease due to its high fluoride content [19] [20]. For dental purposes, fluoride preparations may contain low (0.25 - $1 \mathrm{mg}$ per tablet; 1000 - $1500 \mathrm{mg}$ of fluorine per $\mathrm{kg}$ of toothpaste) or high concentrations (liquids containing 10,000 mg/liter and gels containing $4000-6000 \mathrm{mg} / \mathrm{kg}$ are used for local applications) [15] [17]. NaF is the most commonly used compound in oral caries prevention in the form of fluorinated drinking water, salts or milk, toothpaste, mouthwashes and fluoride tablets that adversely affect liver functions parameters [21]. Although fluoride is everywhere in the environment, the major environmental sources of population exposure to elevated levels of fluoride are water, food, beverages, air, food supplements, and dental products [12] [22] [23]. Daily intakes of fluoride vary widely according to the various sources of exposure. Values ranging from 0.46 to 3.6 - $5.4 \mathrm{mg} /$ day have been reported in several studies [18], but intakes in areas where high-fluoride coal is used indoors or where there is elevated fluoride in drinking-water can be significantly higher [13].

Low concentrations provide protection against dental caries, especially in children. The pre- and post-eruptive protective effects of fluoride (involving the incorporation of fluoride into the matrix of the tooth during its formation, the development of shallower tooth grooves, which are consequently less prone to decay, and surface contact with enamel) increase with concentration up to about $2 \mathrm{mg}$ of fluoride per liter of drinking-water; the minimum concentration of fluoride in drinking-water required to produce it is approximately $0.5 \mathrm{mg} / \mathrm{liter}$ [17]. Excessive intake of fluoride for a prolonged period can produce injurious effects on the blood, teeth, skeleton and soft tissues such as the brain, thyroid, parathyroid glands, liver, and kidneys [24] [25]. Effects of fluoride on the skeleton, such as inhibition of bone mineralization and formation, delayed fracture healing and reductions in bone volume and collagen synthesis, have been observed in a variety of studies in which rats received fluoride orally for periods of 3 - 5 weeks at doses in excess of $16 \mathrm{mg} /$ liter. Bone fragility was increased at concentrations in excess of $64 \mathrm{mg} / \mathrm{liter}$. In subchronic studies, altered bone remodeling, hepatic megalocytosis, nephrosis, mineralization of the myocardium and necrosis or degeneration of the seminiferous tubules in the testis were observed in mice administered fluoride in drinking-water ( $>4.5 \mathrm{mg} / \mathrm{kg}$ of body weight per day) over a period of 6 months [13] [17].

Fluoride is widely used as an anticariogenic agent but excessive ingestion may lead to systemic toxicity. Its biological effects are dependent on the amount, time of exposure and the metabolic handling of ingested fluoride. After being ingested, fluoride is first absorbed in the stomach, followed by its distribution through soft and hard tissues and urine excretion. These events occur in a $\mathrm{pH}$-dependent manner because the coefficient of permeability of lipid bilayer membranes to hydrogen fluoride is much higher than that of ionic fluoride. Therefore, fluoride drives through cell membranes as $\mathrm{HF}$, in response to a $\mathrm{pH}$ gradient between adjacent compartments, going from more acidic to more alka- 
line compartments. The fluoride plasma peak is quickly reached after ingestion, as result of a rapid $\mathrm{pH}$-dependent absorption in the stomach. The small intestine also contributes to fluoride absorption but this event is not $\mathrm{pH}$ dependent. Plasma fluoride levels are rapidly decreased mainly due to fluoride uptake in hard tissues and renal excretion, while the nonabsorbed fluoride is excreted in feces. Thus, plasma fluoride concentration is a result of the relation between the levels of ingestion, and metabolism accounted by its deposition in calcified tissues and excretion. Any systemic, metabolic and genetic alteration can modify fluoride metabolism. They interfere with absorption, excretion and so, with fluoride fate in the body. Imbalances may lead to pathological conditions such as acute and chronic toxicities, dental and skeletal fluorosis [26].

Fluoride renal excretion is one of the most important mechanisms for the regulation of fluoride levels in the body [27]. About $60 \%$ and $45 \%$ of the daily ingested fluoride is excreted in urine of healthy adults and children, respectively [28]. The kidney is a site for potential fluoride toxicity, since it can be exposed to a relatively high concentration of fluoride, and acute renal failure would contribute to the accumulation of fluoride [29]. A relationship between the dose of fluoride and renal tissue injury has been reported [30]. Fluoride salts generate free oxygen radicals which cause lipid peroxidation (LPO) resulting in cell membrane damage and toxicity [31]. Accumulation of mitochondrial ROS (mROS) has been implicated in the pathogenesis of fluorosis [32]. The aim of this review is to highlight on hepatorenal oxidative stress and pathophysiological changes induced by treatment effects of experimental animals with sodium fluoride.

\section{Effect of Sodium Fluoride on the Liver Function}

Aminotransferases (AST and ALT) mediate the catalysis of aminotransfer reactions and are considered to be markers for clinical diagnosis of the liver injury. Alkaline phosphatase (ALP), another marker for hepatic damage, is a hydrolase enzyme responsible for removing the phosphate group from nucleotides and proteins. Lactate dehydrogenase (LDH) is a general indicator of acute or chronic hepatic damage [33].

Fluoride toxicosis caused elevated in the activities of transaminases [6] [24] [34]. Also, Chattopadhyay et al., [35] reported that low (15 mg NaF/L) and relatively high $(150 \mathrm{mg} \mathrm{NaF} / \mathrm{L})$ doses of in vivo fluoride treatment to Swiss albino mice through drinking water caused a disturbance in the liver function.

Vasant and Narasimhacharya, [36] reported that albino rats exposed to fluoride $(100 \mathrm{ppm} \mathrm{NaF})$ through drinking showed significant elevation $(p<0.05)$ in AST, ALT, ALP and ACP activities, plasma glucose and lipid profiles, simulating diabetic and hyperlipidaemic conditions, the antioxidant defence mechanisms of fluoride-exposed rats were compromised, with elevation and decline in LPO and high-density lipoprotein (HDL)-cholesterol, respectively.

Abdel-Wahab, [33] reported that rats treated with NaF orally at a dose of 10 $\mathrm{mg} / \mathrm{kg}$ for 4 weeks showed significantly increased $(p<0.01)$ in serum AST, ALT, 
ALP, LDH, and total bilirubin (TBIL). The mean values increased by $73.1 \%$, $131.8 \%, 63.2 \%, 56.1 \%$, and $310.4 \%$, respectively compared to the control group.

Ismail et al., [37] reported that rats treated intraperitoneally with $10.3 \mathrm{mg} / \mathrm{kg}$ b.wt of $\mathrm{NaF}$ for 30 successive days showed liver damage. NaF caused an elevation in serum transaminases and ALP and reduced serum total protein. It increased all the parameters of lipid profile except the high-density lipoprotein cholesterol level was decreased. Bouasla et al., [38] study the effect of treatment of rats with $100 \mathrm{ppm}$ of $\mathrm{NaF}$ in drinking water for three weeks on the liver. The results showed that $\mathrm{NaF}$ induced liver damages as evidenced by the elevation of plasma aminotransferases (ALT, AST), ALP, LDH activities associated with a decrease in total protein, albumin and bilirubin levels. The rise of the enzymes activities is probably due to the enhancement of cytoplasmic and/or mitochondrial membranes permeability, it could be expected to occur associated with pathology involving damage or necrosis of hepatocytes. on the other hand, The activity of LDH was also significantly increased in rats treated with sodium fluoride. This may be attributed to a generalized increase in membrane permeability and is particularly useful in the diagnosis of muscular dystrophy [38] [39]. The decrease in the proteins levels of fluoride-treated rats might be due to changes in protein synthesis and/or metabolism [38] [40] [41]. Treatment with NaF could suppress $\mathrm{Na}-\mathrm{K}$-activated ATPase, an essential enzyme for the uptake of amino acids by tissues and inhibited incorporation of amino acids into protein [38].

Al-Harbi et al., 2014 [21] evaluated the effects of $\mathrm{NaF}$ on liver function parameters. Mature male mice (weighing 35 - $45 \mathrm{~g}$ and each group of ten animals) were given $\mathrm{NaF}$ (10.3 mg/Kg BW) daily intraperitoneally for 4 weeks. NaF exposure resulted in an increase in the ALT, AST, total protein and LDH levels with respect to the control.

Giri et al., [42] reported that oral administration of $\mathrm{NaF}$ at three dose levels to Wistar rats for 28 days caused a dose-dependent elevation in plasma enzyme activities of ALT, AST, and ALP, hypoproteinaemia and hypoglobulinaemia in rats treated with $\mathrm{NaF}$ as compared to control group.

Emejulu et al., [3] reported that male Wistar albino rats intoxicated with 20 $\mathrm{mg} / \mathrm{Kg}$ bw of $\mathrm{NaF}$ daily by gavage for 35 days showed that significant increases in serum levels of bilirubin, ALT, and AST. From these results, it was observed that oral administration of $\mathrm{NaF}$ for 35 days to adult male rats resulted in a significant alteration of liver function. The corresponding increase in TBIL in our study revealed a deleterious effect of $\mathrm{NaF}$ on liver metabolism in line with the elevation of serum transaminases. Hyperbilirubinaemia is characteristic of impaired bilirubin metabolism involving metabolic disturbances in the liver. This could be as a result of defective conjugation, transport and/or excretion of bilirubin, or overproduction of bilirubin caused by an excessive breakdown of red blood cells due to the toxins from the administered chemical [3].

$\mathrm{Lu}$ et al., [43] reported that ICR mice exposed to different concentration of $\mathrm{NaF}$ $(0 \mathrm{mg} / \mathrm{kg}, 12 \mathrm{mg} / \mathrm{kg}, 24 \mathrm{mg} / \mathrm{kg}$ and $48 \mathrm{mg} / \mathrm{kg}$ ) for a period of 42 days showed that 
$\mathrm{NaF}$ caused oxidative stress and impaired hepatic function, which was strongly supported by increased serum ALT, AST, ALP activities and TBIL contents.

Mohammed and Al-Okaily, [44] investigated that the hepatic dysfunction induced by $\mathrm{NaF}$ in adult male Wister rats. Rats received $\mathrm{NaF} 100$ ppm in drinking tap water for 21 , and 42 days showed a significant decrease in total serum protein and albumin concentrations, whereas significant increase in serum concentrations of TBIL, as well as, ALT, AST, and ALP activities as compared to control. Such change in liver enzymes activity may be accompanied by a change in oxidant/antioxidant status.

Bouasla et al., [38] explained that $\mathrm{NaF}$ caused disturbance of protein synthesizing systems due to suppression of Na-K-ATP ase activity with the inhibited incorporation of amino acids into protein. As well, a reduction in total protein may be due to sodium fluoride-induced either decrease protein synthesis or increased proteolysis, osmotic imbalance caused by LPO [45] and caused depletion of both calcium and magnesium ions might be the reason for a decrease in synthesis of DNA, RNA and then protein synthesis [46] [47]. Fluoride caused oxidative damage by increasing reactive oxygen species (ROS), cytotoxicity, and LPO of the cell membrane [48] with significantly increased apoptosis/necrosis rate [49]. Consequently, lead to leakage of the enzymes from the liver cells. Also, the release of cytochrome $\mathrm{C}$ from mitochondria and the activation pathway of cell death have been seen in SF exposure [50], which was accompanied with a decrease in the antioxidant status of liver [51] with alterations in liver functions.

ALP is a marker enzyme of fluoride toxicosis and bone pathology. The increase in the activity of ALP might be due to the fluoride-induced cell injury to osteoblasts and osteocytes to initiate a repair response resulting in an increased proliferation of osteoblasts, matrix formation and ALP production [42].

\section{Hepatic Histological Changes Induced by Sodium Fluoride}

Shashi, and Thaparb, [52] evaluated that the effect of chronic and acute exposure to $\mathrm{NaF}(5,10,20$, and $50 \mathrm{mg} / \mathrm{kg}$ bw/day) for fifteen weeks on hepatic damage in young albino rabbits. Histopathological examination of the liver of young albino rabbits treated with $\mathrm{NaF}$ revealed increasing degrees of hepatocellular necrosis, degenerative changes, hepatic hyperplasia, extensive vacuolization in hepatocytes, centrilobular necrosis, congested and dilated central vein and blood sinusoids and was associated with small areas of haemorrhages compared with the control group. Dabrowska et al., [7] reported that $\mathrm{NaF}$ induced morphological changes in rat hepatocytes and promoted cells vacuolar degeneration.

Chattopadhyay et al., [35] reported that low (15 $\mathrm{mg} \mathrm{NaF} / \mathrm{L})$ and relatively high (150 mg NaF/L) doses of in vivo fluoride (F) treatment to Swiss albino mice through drinking water caused severe alterations in the liver architecture. Vacuolar degeneration, micronecrotic foci in the hepatocytes, and hepatocellular hypertrophy were evident in the mice exposed to low dose $(15 \mathrm{mg} \mathrm{NaF} / \mathrm{L}$ for 30 days) while sinusoidal dilation with enlarged central vein surrounded by deep-blue erythrocytes was preponderant when treated with the same dose for a 
period of 90 days (Figure 1).

Basha, and Rao, [2] investigated that the histopathological changes in the liver of exposure to $\mathrm{NaF}$ in albino mice. Exposure to $\mathrm{NaF}$ for 15 and 30 days caused cytoplasmic vacuoles in hepatocytes.

Al-Harbi et al., 2014 [21] reported that light microscopic investigation revealed that $\mathrm{NaF}$ exposure induced histopathological alterations in the liver tissues. Liver tissue showing markedly dilated central vein filled by large number of red blood cells and showing severe fatty change of hepatocytes and markedly congested central vein and showing liver cells necrosis in the form of pyknotic nuclei and more eosinophilia of the cytoplasm was also seen (Figure 2). The alterations in transaminases could be expected to occur associated with pathology involving necrosis of the liver.

Inam et al., [31] investigated that the toxic changes in the liver of $\mathrm{NaF}$ treated mice. Adult male albino mice treated with sodium fluoride $(10 \mathrm{mg} / \mathrm{kg} /$ day $)$ for 30 days showed ballooning degeneration of hepatocytes, necrosis, and infiltration of mononuclear cells in hepatic lobules. These deranged histological findings were correlated with elevated levels of liver enzymes in serum. Hamza et al., [53] recorded that histological changes seen in the liver of rats treated with $\mathrm{NaF}$ are characterized by focal hepatocytes necrosis, hepatocyte drop-off (Figure 3),

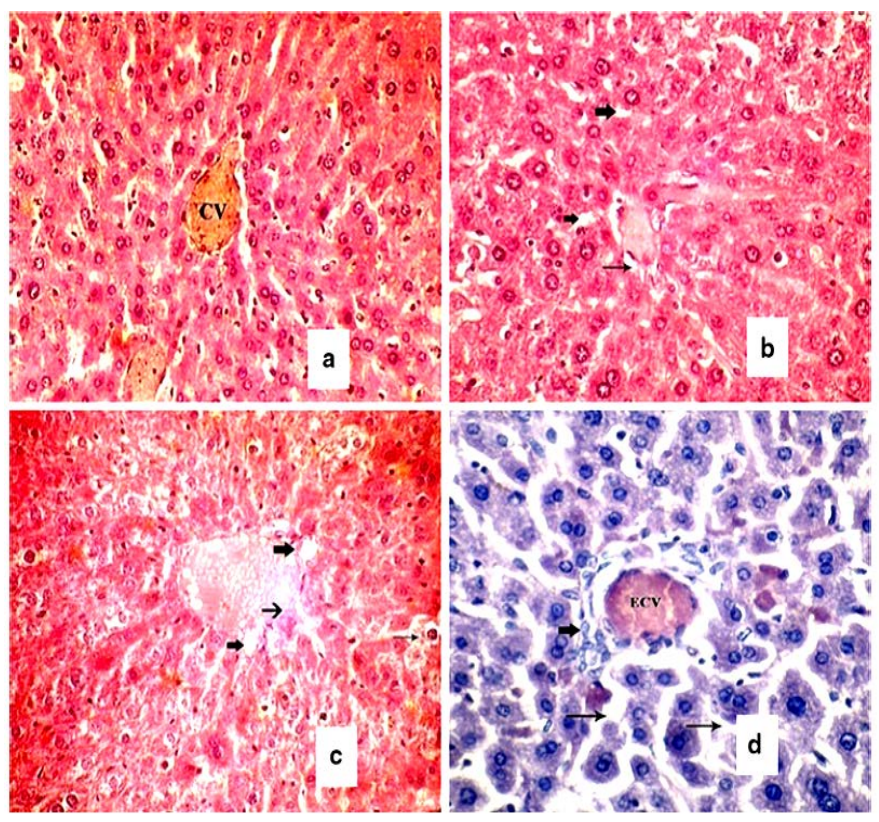

Figure 1. Photomicrographs of the liver of Swiss albino mice showing changes in liver histology. (a) Normal histological appearance of liver tissue of control mice. Central vein (CV); (b) Group II: Vacuolar degenerations (thick arrows) and disruption of epithelium lining (thin arrows) of the central vein; (c) Group III: Extensive vacuolization in cytoplasm (thick arrows), loss of integrity in epithelium lining the central vein (moderately thick arrows) and hepatocellular degeneration (thin arrows); (d) Group IV: Sinusoidal dilation (thin arrows), enlarged central vein (ECV) surrounded peripherally by deep-blue erythrocytes (thick arrows) [35]. 


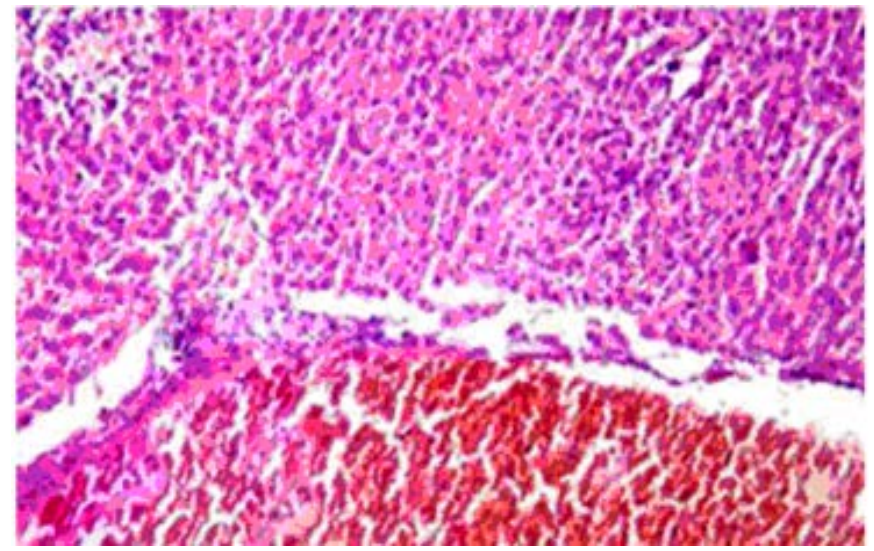

Figure 2. Photomicrograph of the liver of mice treated with $\mathrm{NaF}$ (10.3 mg/kg) Photomicrograph of the liver of rat treated with $\mathrm{NaF}$ shows severe haemorage and congestion, hydropic degeneration $(\mathrm{H}$ and $\mathrm{E} \times 200)[21]$.

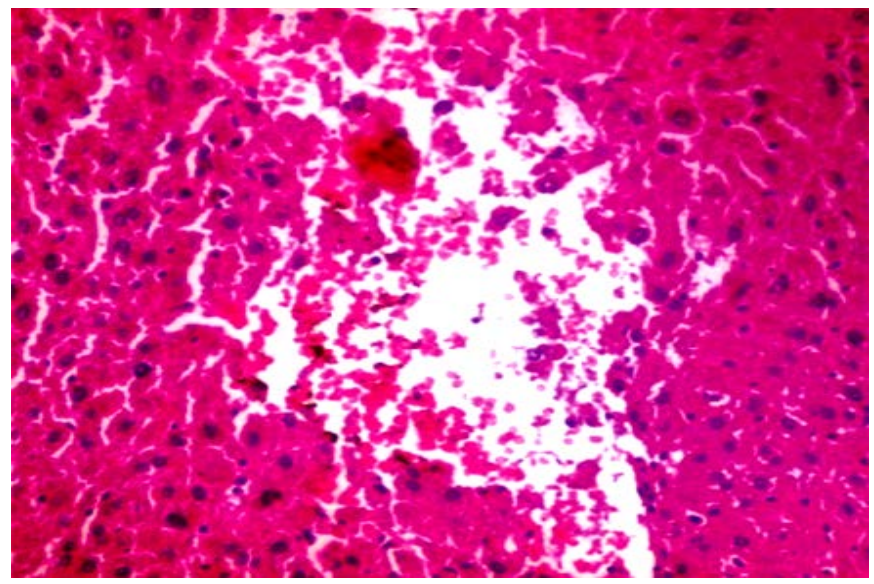

Figure 3. Photomicrograph of the liver of rat treated with $\mathrm{NaF}$ showing focal hepatocytes necrosis with hepatocyte drop-off $(x$ 400) [53].

varying from ballooning degeneration to complete cell necrosis and infiltration of mononuclear cells in hepatic lobules as seen essentially in dams [54].

Samanta et al., [55] reported that male albino rats fed with $5 \mathrm{ppm}, 10 \mathrm{ppm}, 15$ ppm and $20 \mathrm{ppm}$ sodium fluoridated water showed fatty changes, necrosis, hyperplasia, and vacuolization in liver. Ahmad et al., [56] reported that hepatic histopathologies observed in mice treated with $50 \mathrm{ppm}$ of $\mathrm{NaF}$ in drinking water for 10 days were the presence of hepatocellular debris along the centrilobular veins and cytoplasmic vacuolations (leading to increased hepatocellular size), with, simultaneously, diffused and disfigured nuclear dimensions (indicative of necrosis) of the surviving hepatocytes, caused an irregular distribution of the hepatic cords and led to squeezed sinusoids. The induced hepato-pathologies with $\mathrm{NaF}$ exposure may also be contributing towards the regression in neuromuscular performance as this organ bear the main part of the stress of increased metabolite levels and impairment of the ready removal of excretory products. 
Lu et al., [43] found that ICR mice exposed to different concentration of $\mathrm{NaF}$ $(0 \mathrm{mg} / \mathrm{kg}, 12 \mathrm{mg} / \mathrm{kg}, 24 \mathrm{mg} / \mathrm{kg}$ and $48 \mathrm{mg} / \mathrm{kg}$ ) for a period of 42 days showed that $\mathrm{NaF}$ caused oxidative stress and apoptosis, which was strongly supported by the histopathological lesions (Figure 4 and Figure 5). Mohammed and Al-Okaily, [44] found that treatment of adult male Wister rats with NaF 100 ppm in drinking tap water for 21 , and 42 days caused multifocal infiltration of mononuclear cells around the bile duct in the parenchyma associated with congestion of blood vessels, perivascular leukocytes, severe degenerative lesion with vaculation and/or necrosis of surrounding hepatocyte in liver tissues as compared to control.

\section{Hepatic Oxidative Stress Induced by Sodium Fluoride}

Oxidative stress describes a state of uncontrolled overproduction of free radicals beyond a threshold for proper antioxidant neutralization causing damage to macromolecules such as DNA, proteins, and lipids [33] [57]. LPO, as the fundamental index of oxidative damage, has been found to be a major contributor in the toxicity of many xenobiotics [33] [58]. Chattopadhyay et al., [35] found that glutathione level (GSH), and glutathione-s-transferase (GST) activity were reduced in the liver, and its down regulation in liver were positively correlated with histopathological lesion of Swiss albino mice treated with $\mathrm{NaF}$ in drinking water for 30, and 90 days. Abdel-Wahab, [33] reported that rats received $\mathrm{NaF}$ orally at a dose of $10 \mathrm{mg} / \mathrm{kg}$ for 4 weeks showed a significant increase in LPO whereas the level of reduced glutathione and the activity of superoxide dismutase (SOD), catalase (CAT), glutathione S-transferase and glutathione peroxidase

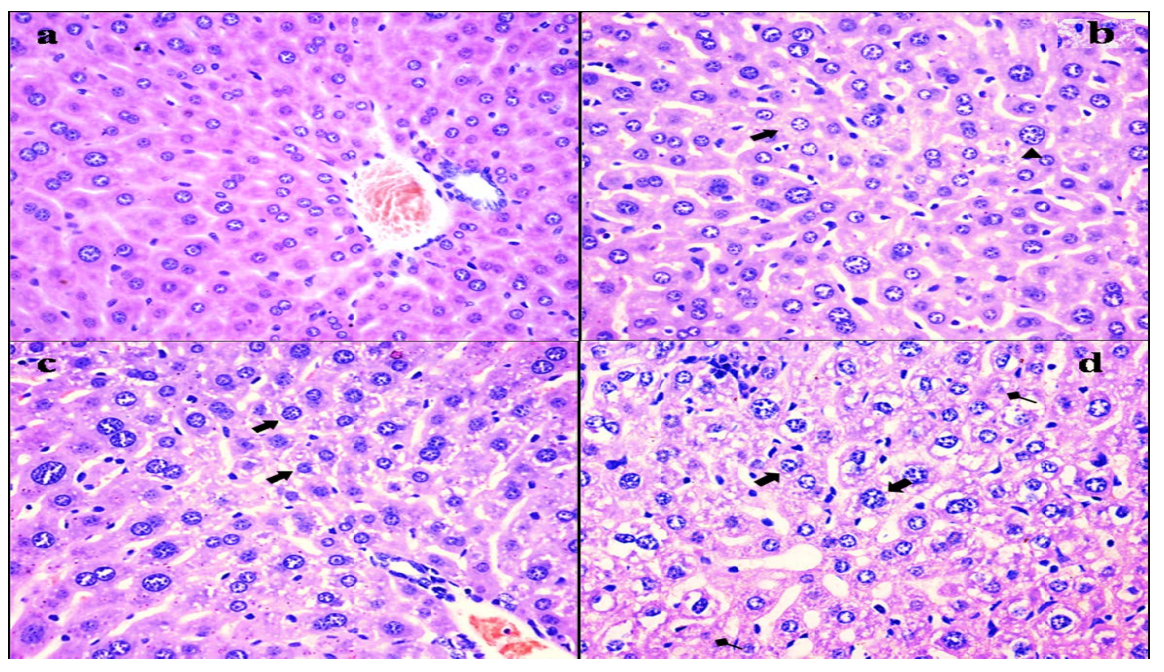

Figure 4. Photomicrographs of the liver of mice treated with NaF for 21 days shows histopathological changes in the liver. (a) The control group ( $\mathrm{H} \& \mathrm{E} \times 400$ ); (b) The 12 $\mathrm{mg} / \mathrm{kg}$ group. Hepatocytes are swelled $(\boldsymbol{\Delta})$ and show slight granular and vacuolar degeneration (, $\mathrm{H} \& \mathrm{E} \times 400$ ); (c) The $24 \mathrm{mg} / \mathrm{kg}$ group. Hepatocytes show granular and vacuolar degeneration (, $\mathrm{H} \& \mathrm{E} \times 400$ ); (d) The $48 \mathrm{mg} / \mathrm{kg}$ group. Hepatocytes show obvious granular and vacuolar degeneration $(\boldsymbol{\uparrow})$. Necrotic hepatic cells $(\boldsymbol{\top})$ are observed $(\mathrm{H} \& \mathrm{E} \times 400)[43]$. 


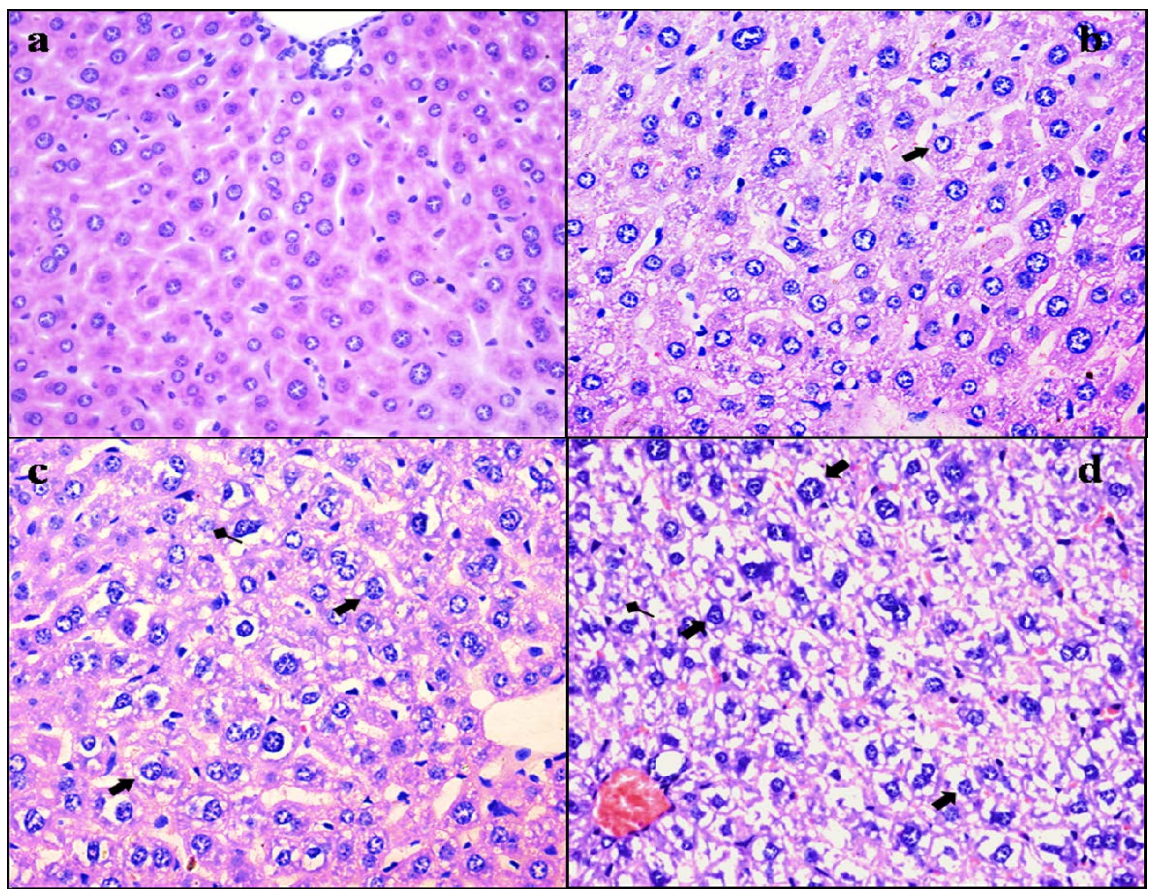

Figure 5. Photomicrographs of the liver of mice treated with $\mathrm{NaF}$ for 42 days shows histopathological changes in the liver. (a) The control group (H \& $\mathrm{E} \times 400)$; (b) The 12 $\mathrm{mg} / \mathrm{kg}$ group. Hepatocytes show granular and vacuolar degeneration (, $\mathrm{H} \& \mathrm{E} \times 400$ ); (c) The $24 \mathrm{mg} / \mathrm{kg}$ group. Hepatocytes show obvious granular and vacuolar degeneration († ). Also, necrotic hepatocytes are observed ( $\mathbf{\uparrow}, \mathrm{H} \& \mathrm{E} \times 400$ ); (d) The $48 \mathrm{mg} / \mathrm{kg}$ group. Hepatocytes show marked vacuolar degeneration ( $)$. Necrotic hepatocytes are observed ( $\mathbf{\top})$. And hepatic cords are disorganized or disappeared $(\mathrm{H} \& \mathrm{E} \times 400)$ [43].

(GPx) were reduced in hepatic tissues. Fluoride consumption is associated with the production of free radicals which can react with polyunsaturated fatty acids to yield lipid hydroperoxides which in turn initiates a lipid-radical chain reaction leading to oxidative damage to the cell membrane [33].

Lu et al., [43] reported that ICR mice exposed to different concentration of $\mathrm{NaF}(0 \mathrm{mg} / \mathrm{kg}, 12 \mathrm{mg} / \mathrm{kg}, 24 \mathrm{mg} / \mathrm{kg}$ and $48 \mathrm{mg} / \mathrm{kg}$ ) for a period of 42 days showed that $\mathrm{NaF}$ caused oxidative stress and apoptosis in the liver. NaF-caused oxidative stress was accompanied by increasing ROS and MDA levels and decreasing mRNA expression levels and activities of SOD, CAT, GSH, GPx and GST. NaF induced apoptosis via tumor necrosis factor receptor-1 (TNF-R1) signaling pathway, which was characterized by significantly increased mRNA and protein expression levels of TNF-R1, Fas-associated death domain (FADD), TNFR-associated death domain (TRADD), cysteine aspartate-specific protease- 8 (caspase-8) and cysteine aspartate-specific protease-3 (caspase-3) in dose- and time-dependent manner. Oxidative stress is involved in the process of apoptotic occurrence and can be triggered by promoting ROS production and reducing antioxidant function.

NaF-induced hepatic oxidative stress and apoptosis through the TNF-R1 signal pathway [43]. MDA contents were increased in the liver of NaF-treated groups, which were consistent with the increased ROS production levels. The 
imbalance between ROS and the antioxidants can cause oxidative stress. The increased ROS levels may indicate the earlier studies on the effect of $\mathrm{NaF}$ on the antioxidant enzymes [43] [59] [60] [61]. SOD and CAT are important antioxidant enzymes, playing a major role in ROS elimination [43] [62]. Non-enzymatic scavengers such as GSH have also involved in scavenging ROS, and the GSH dysfunction could aggravate the organ injury [43] [63]. GSH-Px can promote the reaction between GSH and $\mathrm{H}_{2} \mathrm{O}_{2}$ in order to achieve the purpose of eliminating peroxide [64]. Therefore, the decreased GSH-Px activities caused by $\mathrm{NaF}$ in this study are closely correlated to the reduction of GSH contents [43]. NaF not only can promote the ROS production, but also inhibit the antioxidant enzyme mRNA expression in the liver. Then the imbalance between ROS and antioxidative function leads to the oxidative stress, which contributes to the occurrence of hepatocellular apoptosis. It has been accepted that oxidative stress is an apoptotic inducer and some agents that induce apoptosis are either oxidants or stimulators of cellular oxidative metabolism [40].

\section{Effect of Sodium Fluoride on the Kidney Function}

Changes in serum urea, creatinine, $\mathrm{Na}^{+}$, and $\mathrm{Cl}^{-}$are associated with impairment of renal function [3] [65], and the major route of excretion of fluoride is by the kidneys. NaF administration may have caused kidney damage resulting in altered kidney metabolism, dyshomeostasis of electrolyte profile and impairment in kidney clearance of urea and elevated creatinine [3].

Zhan et al., [66] found that the serum urea nitrogen and creatinine were significantly increased and $\mathrm{Na}^{+}$and $\mathrm{Cl}^{-}$were significantly decreased in young pigs supplemented with 100 , and $250 \mathrm{mg} / \mathrm{kg} \mathrm{NaF}$ in the basal diet for 50 days. The elevated serum levels of urea nitrogen, and creatinine, and the decreased serum levels of serum $\mathrm{Na}^{+}$and $\mathrm{Cl}^{-}$indicate the reduced ability of the kidney to eliminate the toxic metabolic substances and reabsorb the metal and non-metal ions. Fluoride is a serious health hazard across several nations, and chronic intake of fluoride deranges the carbohydrate, lipid and antioxidant metabolism in general. Ismail et al., [37] reported that rats treated intraperitoneally with $10.3 \mathrm{mg} / \mathrm{kg}$ b.w of $\mathrm{NaF}$ for 30 successive days showed impairment of kidney function. $\mathrm{NaF}$ caused a reduction in serum levels of uric acid and creatinine.

Al-Harbi et al., [67] exposure of mature male mice to $\mathrm{NaF}$ (i.p. $10.3 \mathrm{mg} / \mathrm{kg}$ / day) for 4 weeks resulted in an increase in the urea, creatinine, triglycerides compared to the control group.

Giri et al., [42] recorded that increases in blood urea nitrogen, creatinine and uric acid levels in Wistar rats treated with $\mathrm{NaF}$ for 28 days as compared to control group. These observations might be attributed to fluoride-induced renal failure.

Emejulu et al., [3] recorded that the serum urea, creatinine, sodium, chloride ion levels were significantly increased in NaF-treated rats compared to normal control. The observed increase in sodium concentration may be attributed to an increased retention of sodium ion or may be contributed by $\mathrm{Na}^{+}$ion resulting 
from the administered NaF. The elevated serum concentration of $\mathrm{Na}^{+}$and $\mathrm{Cl}^{-}$ ions indicate the reduced ability of the kidney to eliminate the toxic metabolic substances and reabsorb the metal and non-metal ions. Increase in chloride concentration may be attributed to retention or a decreased clearance of $\mathrm{Cl}^{-}$ which may be due to a preferential excretion of $\mathrm{F}^{-}$anion instead of $\mathrm{Cl}^{-}$anion [3].

\section{Renal Histological Changes Induced by Sodium Fluoride}

Shashi et al., [68] demonstrated that, in rabbits exposed to high doses of $\mathrm{NaF}$, the cytoarchitecture of kidneys exhibited increased amounts of cloudy swellings. Zhan et al., [66] investigated that the effects of chronic fluoride exposure (basal diet additionally supplemented, respectively, with 0,100 , and $250 \mathrm{mg} / \mathrm{kg} \mathrm{NaF}$ ) in young pigs on kidney integrity and histological structure. Results obtained after 50 days indicated that supplemental fluoride-treatment caused severe renal histological changes as well as increased renal cell apoptosis. Authors found that atrophic glomeruli, glomerular capsule and tubule dilatation, severe tubule leakage, and necrosis of glomeruli and tubules (Figure 6). These findings show that chronic excessive fluoride exposure is deleterious to kidney structure and function of pigs.

Chattopadhyay et al., [35] found that severe alterations in the kidney architectures in Swiss albino mice treated with $\mathrm{NaF}$ in drinking water for 30 and 90 days. Blood filled spaces, the disintegration of tubular epithelium, and atrophy of glomeruli was also recorded in the kidney of the same treatment group.

Basha, and Rao, [2] reported that exposure of albino mice to NaF for 15 and 30 days results in necrosis in glomerules, Convoluted tubules and Bowman's capsule lumen in the kidney.

Poesina et al., [69] investigate the toxic effects of $\mathrm{NaF}$ on the kidney in two consecutive generations of NMRI mice. Histopathological observation of the kidney has revealed granular dystrophy of the renal tubules, necrosis of the endothelial cells and of the mesangial cells of renal glomerulus (Figure 7). The study indicates that different $\mathrm{NaF}$ treatments produce some pathological aspects of the kidneys and influence the urinary elimination of fluoride in two consecutive generations of mice.

Hamza et al., [53] reported that samples of renal tissue from NaF-treated rats, exhibiting tubular cell necrosis; tubular lumen dilation; foci of denuded basement membrane; swelling, flattening or loss of proximal tubular cells; interstitial inflammatory cell infiltration; tubular degeneration; glomerular spaces and focal glomerulosclerosis with mild tubular hemorrhage (Figure 8).

Samanta et al., [55] reported that male albino rats fed with 5 ppm, 10 ppm, 15 ppm and $20 \mathrm{ppm}$ sodium fluoridated water showed deformed glomeruli, tubal dilation and leakage, changes in proximal, distal and collecting tubules, adhesion between visceral and parietal layers of Bowman's capsule, interstitial hemorrhage, degeneration of cytoplasm and infiltration by inflammatory cells in the kidney tissues. 


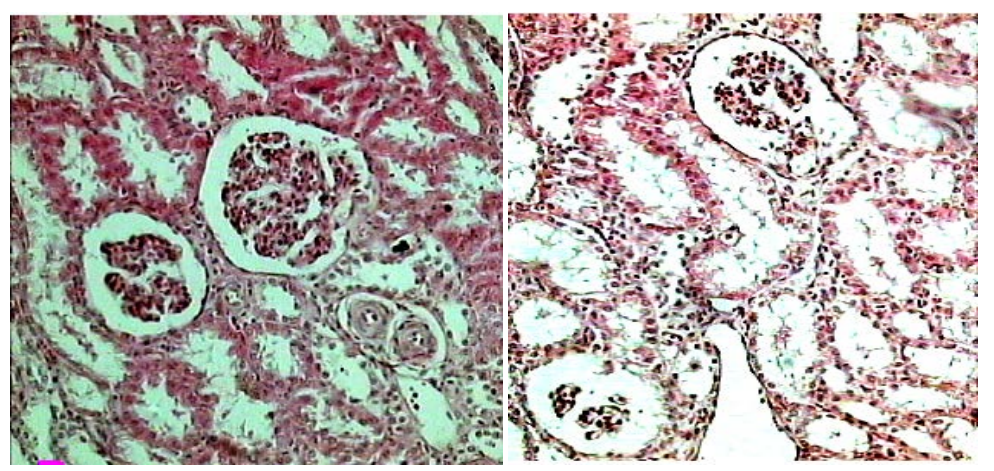

Figure 6. Photomicrographs of young pigs treated with NaF showing necrosis of glomeruli and tubules, atrophic glomeruli, glomerular capsule tubules dilatation, and severe tubular leakage appeared [66].

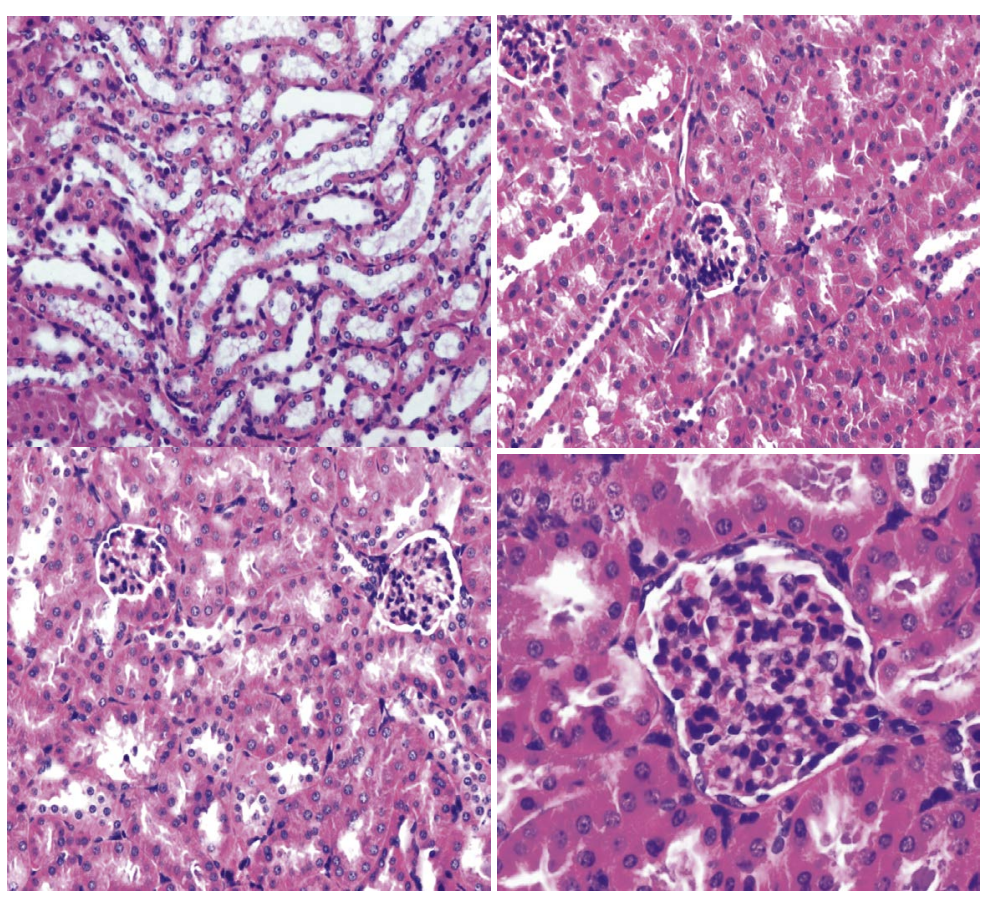

Figure 7. Photomicrographs of NMRI mice treated with NaF showing granular dystrophy of the renal tubules, necrosis of the endothelial cells and of the mesangial cells of renal glomerulus [69].

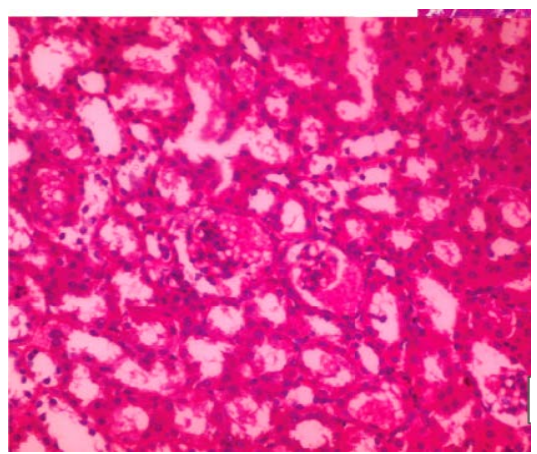

Figure 8. Photomicrograph of rats treated with $\mathrm{NaF}$ showing focal glomerulosclerosis with mild tubular hemorrhage $(\times 400)$ [53]. 
Ahmad et al., [56] found that the nephronal micrometric data for the endothelial brush border thickness of the proximal tubules and the CSAs of glomeruli and proximal tubules in mice treated with $50 \mathrm{ppm}$ of $\mathrm{NaF}$ in drinking water for 10 days. The induced nephronal pathologies with $\mathrm{NaF}$ exposure may also be contributing towards the regression in neuromuscular performance as these organs bear the main part of the stress of increased metabolite levels and impairment of the ready removal of excretory products [56].

Shashi, and Kaur, [70] reported that oral administration of 300 and $600 \mathrm{ppm}$ of $\mathrm{NaF}$ to Wister albino rats for 40 days caused histopathological alterations in the kidney. In rats treated with $300 \mathrm{mg} / \mathrm{kg}$ b.w./day $\mathrm{NaF}$ for 40 days, there was significant morpho pathological damage to the renal cortex (Figure 9). The glomeruli exhibited different forms of degeneration. Some glomeruli appeared markedly lobulated whereas others appeared shrunken with a moderately congested capillary loops and an expanded Bowman's capsule. Some renal convoluted tubules were manifested either damaged with sloughing off their tubular epithelial cells and exhibited abnormal marked dilatation of their lumens. The oedematous and vacuolar tissue, vacuolar dystrophy, tubular atrophy, presence of protein casts in lumen were also visible. The glomeruli revealed hypertrophic changes as compared to control. Extensive interstitial hemorrhage was well demonstrated in the peritubular and perivascular areas along with degenerated glomeruli (Figure 9). In rats treated with $600 \mathrm{mg} / \mathrm{kg}$ b.w./day $\mathrm{NaF}$ for 40 days there was dissolution of renal cortex. The tubular epithelia of proximal convoluted tubules showed vacuolar degeneration of their cytoplasm giving them cloudy swelling appearance and markedly dilated lumen. Some tubular epithelial cells exhibited cell swelling with lysis of their cytoplasm, vacuolation and organelles. The renal tubules were dilated and atrophied. The shape of proximal and distal convoluted tubules was distorted (Figure 10).

Yadav et al., [14] reported that catfish (Heteropneustis fossilis) were exposed to $35 \mathrm{mg} \mathrm{F} / \mathrm{L}$ and $70 \mathrm{mg}$ F/L of water for 45 and 90 days. Histopathological study of kidney revealed renal degeneration and hypertrophy of renal tubules epithelial cells and dilation in the glomeruli. These alterations in kidney architecture might be due to the generation of ROS by fluoride which plays a deleterious role in causing nephrotoxicity.

Fluoride increased the permeability by affecting the communicating units between endothelia of the venules and capillaries, as a result edema, hemorrhage, and necrosis occurred [70]. Necrosis may be due to the depletion of ATP, which leads to the death of the cells [70] [71]. Urinary spaces dilation may be the result of high pressure across the glomerular capillaries [70] [72]. Glomerular hypertrophy may be responsible for the podocytes abnormalities [70] [73]. Renal medullary necrosis occurs as a primary manifestation of the renal disease. The mechanism of which is poorly understood, but it seems to involve a vascular change. Also, prostaglandin synthetase is found in the kidney, primarily in the medulla, and inhibition of this enzyme resulted in decreased production of 


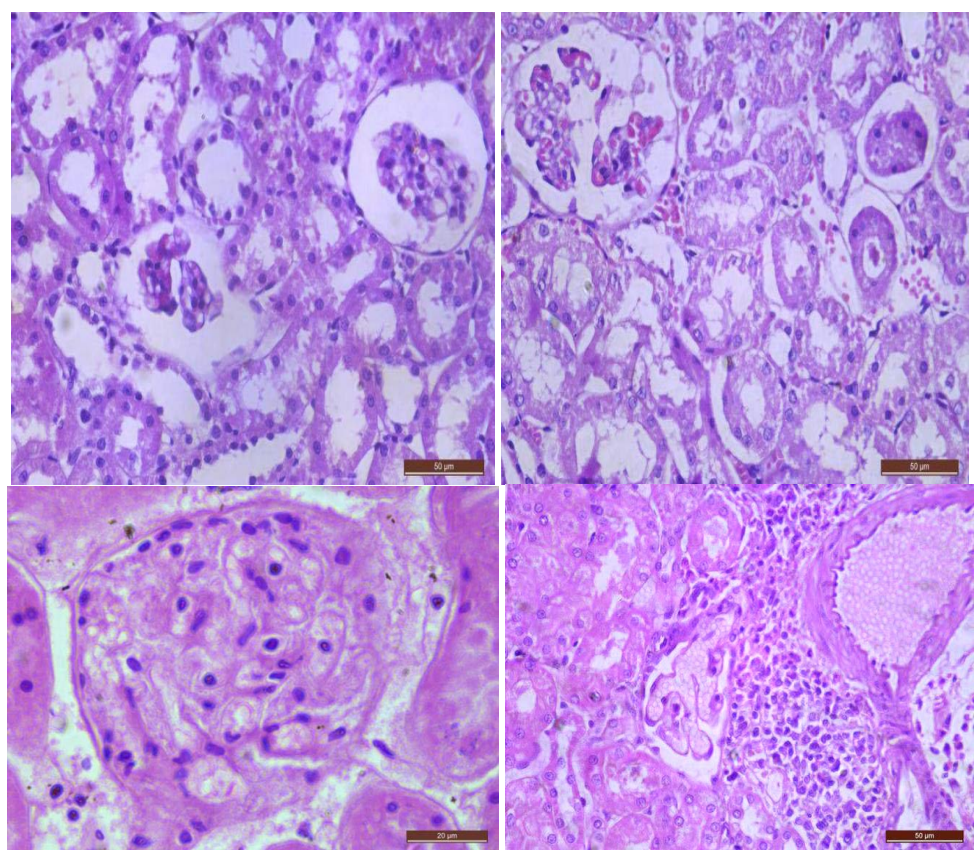

Figure 9. Photomicrographs of the kidney of rat treated with $300 \mathrm{mg} / \mathrm{kg}$ b.w./day of $\mathrm{NaF}$ showing renal tubules with marked dilated lumen, denuded epithelium lining, shrunken glomeruli, expanded Bowman's capsule, with oedematous, vacuolated areas, desquamated epithelial cells in the lumina of the tubules, intratubular casts, inflammatory cells infiltrated in the perivascular area, and showing degenerated glomeruli $(\mathrm{H} \& \mathrm{E} \times$ 400). Photomicrograph under oil immersion lenses show a hypertrophied glomerulus. $\mathrm{H} \& \mathrm{E} \times 1000$ [70].

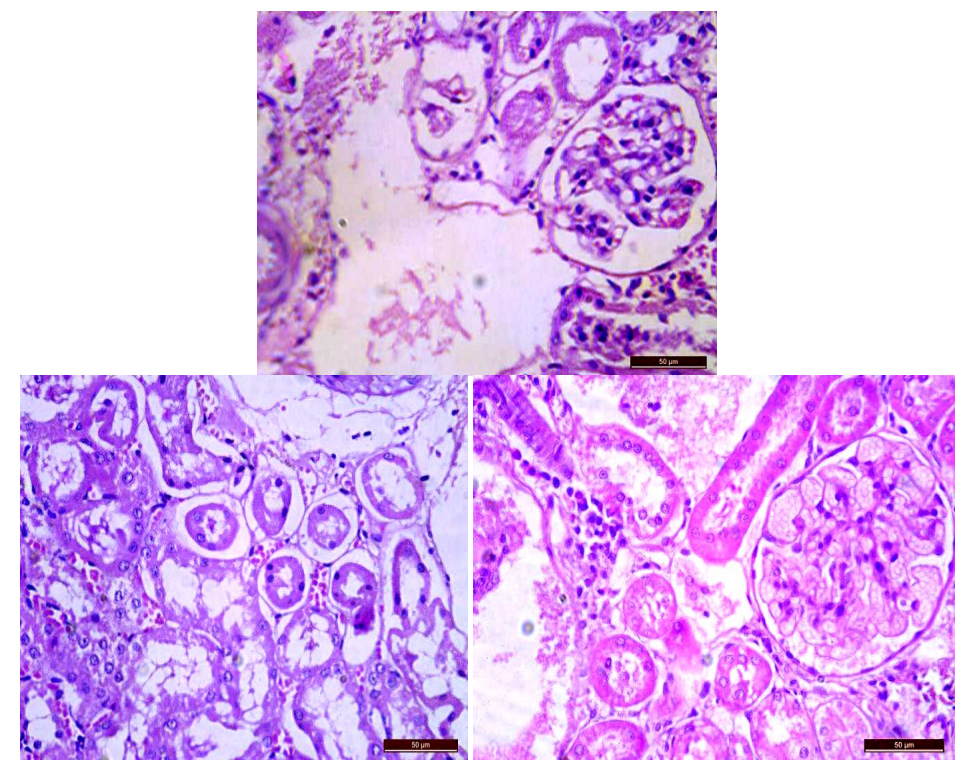

Figure 10. Photomicrographs of the kidney of rat treated with 600 $\mathrm{mg} / \mathrm{kg}$ b.w./day of NaF showing with shrunken glomeruli, vacuolar glomerular dissolution in cortex, multifocal vacuolation of cytoplasm in a segment of proximal convoluted tubule, atrophy of some renal tubules, mesangial and endothelial capillary hypercellularity, and thick basement membrane, and vacuolation of cytoplasm in tubules $(\mathrm{H} \& \mathrm{E} \times 400)$ [70]. 
prostaglandin E2 (PGE2) and loss of its vasodilatory effect on juxtamedullary arterioles [70] [74]. Many renal tubules of the rat kidneys showed marked degenerative lesions under the effect of sodium fluoride. This is justifiable since the renal tubules are particularly sensitive to toxic influences, because they have high oxygen consumption and vulnerable enzyme systems, and they have complicated transport mechanisms that may be used for transport of toxins and may be damaged by such toxins. Such degenerative changes were markedly pronounced in the proximal convoluted tubules [70].

\section{Renal Oxidative Stress Induced by Sodium Fluoride}

Chattopadhyay et al., [35] found that GSH, and GST activity were reduced, and induction of heat shock protein 70 (Hsp 70) expression in kidney of Swiss albino mice treated with $\mathrm{NaF}$ in drinking water for 30 and 90 days.

Fluoride is known to cause increased oxidative stress in the kidney [75]. Significantly high levels of LPO and CAT and low levels of reduced glutathione, SOD, glutathione reductase, and GSH-Px are found in renal tissues of fluoride-treated rats [75] [76].

Song et al., [32] reported that NaF treatment impaired mitochondrial ultrastructure decreased cell viability and increased apoptosis in TCMK-1 cells. Oxidative stress, detected by mROS and 8-Hydroxy-2'-deoxyguanosine (8-OHdG) were higher in NaF-treated cells, accompanied by a decreased level of reduced glutathione. NaF reduces manganese superoxide dismutase (SOD2) expression through SIRT3-mediated DNA-binding activity of FoxO3a and decreases SOD2 activity by inhibiting SIRT3-mediated deacetylation. The study provides new insights into a critical NRF2/PGC-1 $\alpha$-SIRT3 pathway in response to $\mathrm{NaF}$ induced nephritic oxidative injury. Moreover, the mechanistic study revealed that ERK1/2 activation was associated with increased apoptosis induced by NaF. These data suggest that PGC- $1 \alpha$ interacts with NFR2, not ERR $\alpha$, as a transcriptional co-activator, which is responsible for the expression and downstream effects of SIRT3 in NaF-induced renal cells injury. Since mitochondrial ROS accumulation and subsequent oxidative stress have been demonstrated to activate a variety of signaling pathways, among which MAPK pathway has been implicated in NaF-induced apoptosis [32]. Acetylation in SOD2 is mediated by SIRT3, the loss of which leads to the deacetylation and inactivation of SOD2, which is connected with mROS accumulation in renal cells induced by $\mathrm{NaF}$ apoptosis [32]. NaF induces apoptosis in the kidney of rats through caspase-mediated pathways and DNA damage [77] [78].

Yadav et al., [14] reported that catfish (Heteropneustis fossilis) were exposed to $35 \mathrm{mg} \mathrm{F} / \mathrm{L}$ and $70 \mathrm{mg} \mathrm{F} / \mathrm{L}$ of water for 45 and 90 days. There was decrease activity of GSH, SOD, CAT, GPx, and Protein in kidney tissues and increase the activity of LPO and GST. These observations indicate that subchronic exposure to the fluoride is capable of inducing oxidative stress in fish. The rise in LPO may be due to the increase in the generation of the free radicals. These free radicals attack cell structures within the body, causing damage to the cell membrane 
and enzyme systems [14]. The reduction in the GSH level may be due to direct conjugation of GSH with electrophiles species which are produced increasingly by fluoride exposure or due to inhibition of enzymes such as glutathione reductase, GSH-Px, glucose-6-phosphate dehydrogenase etc. which are involved in GSH synthesis and regeneration [14] [79]. The decreased activity of SOD in the kidney tissue might cause the accumulation of ROS. Fluoride exposure is considered to generate anion superoxide [14] [80].

\section{Conclusion}

It can be concluded that, administration of $\mathrm{NaF}$ to experimental animals induced oxidative stress, serious hepatorenal histopathological changes, and disturbance in liver and kidney functions (Figure 11 and Figure 12). So, human

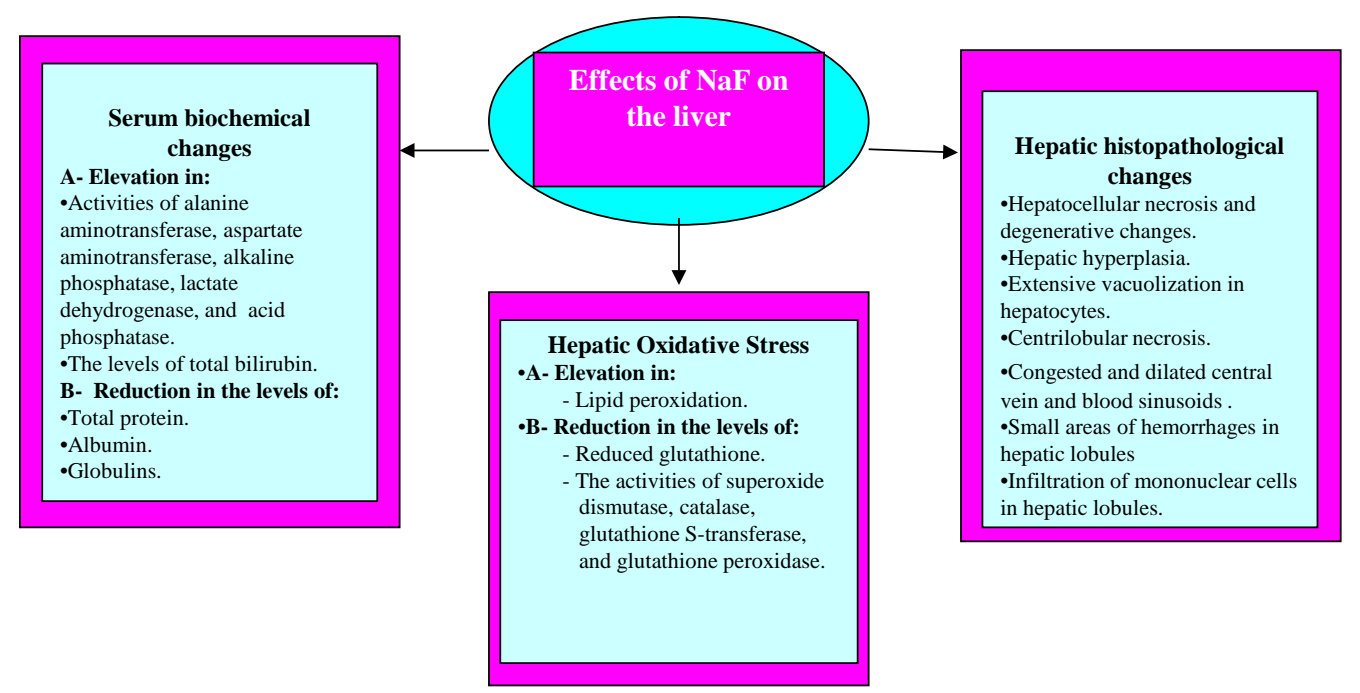

Figure 11. Effects of sodium fluoride on the liver.

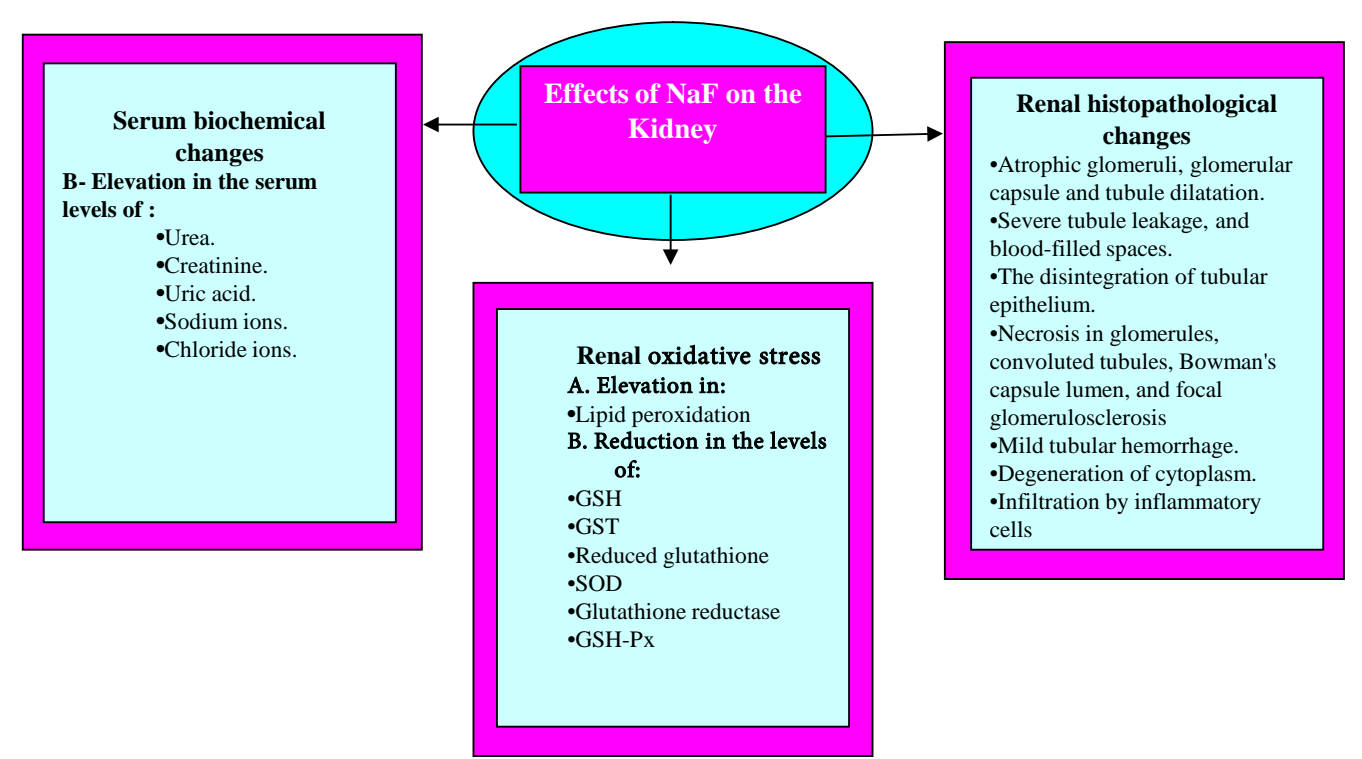

Figure 12. Effects of sodium fluoride on the kidney. 
should be advised to decrease exposure to $\mathrm{NaF}$ to decrease the harmful effects of $\mathrm{NaF}$ on liver and kidney.

\section{References}

[1] Gale, R.P., Spakes, R.S. and Golde, D.W. (1978) Bone Marrow Origin of Hepatic Macrophages (Kupffer Cells) in Humans. Science, 201, 937-938. https://doi.org/10.1126/science.356266

[2] Basha, S.K. and Rao, K.J. (2014) Sodium Fluoride Induced Histopathalogical Changes in Liver and Kidney of Albino Mice. Acta Chimica and Pharmaceutica Indica, 4, 58-62.

[3] Emejulu, A.A., Alisi, C.S., Asiwe, E.S., Igwe, C.U., Nwogu, L.A. and Onwuliri, V.A. (2016) Renal and Hepato-Protective Effects of Irvingia gabonensis Juice on Sodium Fluoride-Induced Toxicity in Wistar Rats. Journal of Clinical Toxicology, 6, 296. https://doi.org/10.4172/2161-0495.1000296

[4] Choi, J.J., Moffett, B.S., McDade and Palazzo, D.L. (2011) Altered Gentamicin Serum Concentration in Obese Pediatric Patients. The Pediatric Infectious Disease Journal, 30, 347-349. https://doi.org/10.1097/INF.0b013e3181ff023e

[5] Azab, A.E., Fetouh, F.A. and Albasha, M.O. (2014) Nephroprotective Effects of Curcumin, Rosemary and Propolis against Gentamicin Induced Toxicity in Guinea Pigs: Morphological and Biochemical Study. American Journal of Clinical and EXperimental Medicine, 2, 28-35.

[6] Guo-Ving, X., Sun, G. and Shun, Y. (2003) Oxidative Stress from Fluoride Induce Hepatotoxicity in Rats. Fluoride, 36, 25-29.

[7] Dabrowaska, E., Letko, R. and Balunowska, M. (2006) Effect of Sodium Fluoride on the Morphological Picture of the Rat Liver Exposed to NaF in Drinking Water. $A d$ vances in Medical Sciences, 51, 91-95.

[8] World Health Organization Regional Office for Europe (2000) Air Quality Guidelines for Europe. 2nd Edition, World Health Organization.

[9] Mishra, P.C. and Arpradhan, K. (2007) Prevalence of Fluorosis among School Children and Cattle Population of Hirakud Town in Orissa. The Bioscan, 2, 31-36.

[10] Okibe, F.G., Ekanem, E.J., Paul, E.D., Shallangwa, G.A., Ekwumemgbo, P.A., Sallau, M.S. and Abanka, O.C. (2010) Fluoride Content of Soil and Vegetables from Irrigation Farms on the Bank of River Galma, Zaria, Nigeria. Australian Journal of Basic and Applied Sciences, 4, 779-784.

[11] Lewandowska, A., Falkowska, L. and Jozwik, J. (2013) Factors Determining the Fluctuation of Fluoride Concentrations in PM10 Aerosols in the Urbanized Coastal Area of the Baltic Sea (Gdynia, Poland). Environmental Science and Pollution Research, 20, 6109-6118. https://doi.org/10.1007/s11356-013-1592-2

[12] Shitaw, K.N. (2015) Studies on the Levels of Fluoride in Selected Spices Cultivated and Consumed in Ethiopia. Master of Science in Analytical Chemistry, Department of Chemistry, College of Natural Sciences, Addis Ababa Universtiy, Addis Ababa.

[13] IPCS (2002) Fluorides. International Programme on Chemical Safety (Environmental Health Criteria 227), World Health Organization, Geneva.

[14] Yadav, B. and Garg, A. (2014) Impact and Remedial Strategy of Fluoride in Ground Water-A Review. International Journal of Engineering Research and Applications, 4, 570-577.

[15] Slooff, W., Eerens, H.C., Janus, J.A., Ros, J.P., Janssen, P.J., Knaap, A.G., Lagas, P., 
Matthijsen, A.J., Reijnders, H.F., Struijs, J. and van de Wiel, H.J. (1988) Basis Document Fluoriden. National Institute of Public Health and Environmental Protection, Bilthoven, Report No. 758474005.

[16] US EPA (1985) Drinking Water Criteria Document on Fluoride. US Environmental Protection Agency, Office of Drinking Water, Washington DC, TR-823-5.

[17] Fawell, J.K., Ohanian, E., Giddings, M., Toft, P., Magara, Y. and Jackson, P. (2004) Fluoride in Drinking-Water, Background Document for Development of WHO Guidelines for Drinking-Water Quality. 3rd Edition, World Health Organization, Geneva.

[18] IPCS (1984) Fluorine and Fluorides. International Programme on Chemical Safety (Environmental Health Criteria 36), World Health Organization, Geneva.

[19] Pehrsson, P.R., Patterson, K.Y. and Perry, C.R. (2011) The Fluoride Content of Select Brewed and Microwave-Brewed Black Teas in the United States. Journal of Food Composition and Analysis, 24, 971-975. https://doi.org/10.1016/j.jfca.2010.12.013

[20] Waugh, D.T., Potter, W., Limeback, H. and Godfrey, M. (2016) Risk Assessment of Fluoride Intake from Tea in the Republic of Ireland and Its Implications for Public Health and Water Fluoridation. International Journal of Environmental Research and Public Health, 13, 259. https://doi.org/10.3390/ijerph13030259

[21] Al-Harbi, M.S., Hamza, R.Z. and Dwari, A.A. (2014) Ameliorative Effect of Selenium and Curcumin on Sodium Fluoride Induced Hepatotoxicity and Oxidative Stress in Male Mice. Journal of Chemical and Pharmaceutical Research, 6, 984-998.

[22] Everett, E.T. (2011) Effects of Fluoride on the Formation of Teeth and Bones, and the Influence of Genetics. Journal of Dental Research, 90, 552-560. https://doi.org/10.1177/0022034510384626

[23] Tokalioglu, S., Kartal, S. and Sahin, U. (2004) Determination of Fluoride in Various Samples and Some Infusions using a Fluoride Selective Electrode. Turkish Journal Chemistry, 28, 203-211.

[24] Shanthakumari, D., Srinivasalu, S. and Subramanian, S. (2004) Effect of Fluoride Intoxication on Lipid Peroxidation and Antioxidant Status in Experimental Rats. Toxicology, 204, 214-228. https://doi.org/10.1016/j.tox.2004.06.058

[25] Akdogan, M., Kaleli, S., Yazar, H., Desdicioglu, R. and Yuvaci, H.U. (2016) Effect of High-Dose Fluoride on Antioxidant Enzyme Activities of Amniotic Fluid in Rats. Journal of the Pakistan Medical Association, 66, 435-438.

[26] Buzalaf, C.P., Leite, A.D.L. and Buzalaf, M.A.R. (2015) Fluoride Metabolism. In: Preedy, V.R., Ed., Food and Nutritional Components in Focus No. 6, Fluorine. Chemistry, Analysis, Function and Effects, Royal Society of Chemistry, Chapter 4. http://www.rsc.org

[27] Buzalaf, M.A. and Whitford, G.M. (2011) Fluoride Metabolism. Monographs in Oral Science, 22, 20-36. https://doi.org/10.1159/000325107

[28] Villa, A., Anabalon, M., Zohouri, V., Maguire, A., Franco, A.M. and Rugg-Gunn, A. (2010) Relationships between Fluoride Intake, Urinary Fluoride Excretion and Fluoride Retention in Children and Adults: An Analysis of Available Data. Caries Research, 44, 60-68. https://doi.org/10.1159/000279325

[29] Chinoy, N.J. and Shah, S.D. (2004) Beneficial Effects of Some Antidotes in Fluoride and Arsenic Induced Toxicity in Kidney of Mice. Fluoride, 37, 151-161.

[30] Dote, T., Kono, K., Usuada, K., Nishiura, H., Tagawa, T. and Shimahara, M. (2000) Pharmacokinetic Parameters in Rats with Acute Renal Damage Caused by Intra- 
venous High Dose of Fluoride. Fluoride, 33, S9-S10.

[31] Inam, F., Tahir, M., Lone, K.P. and Latif, W. (2015) Protective Effect of Vitamin E on Fluoride Induced Hepatotoxicity. Biomed, 31, 1-6.

[32] Song, C., Fu, B., Zhang, J., Zhao, J., Yuan, M., Peng, W., Zhang, Y. and Wu, H. (2017) Sodium Fluoride Induces Nephrotoxicity via Oxidative Stress-Regulated Mitochondrial SIRT3 Signaling Pathway. Scientific Reports, 7, 672. https://doi.org/10.1038/s41598-017-00796-3

[33] Abdel-Wahab, W.M. (2013) Protective Effect of Thymoquinone on Sodium Fluoride-Induced Hepatotoxicity and Oxidative Stress in Rats. The Journal of Basic and Applied Zoology, 66, 263-270. https://doi.org/10.1016/j.jobaz.2013.04.002

[34] Qujeq, D., Laghaie, B., Gholipour, A., Solimani, N. and Hassenzadeh, S. (2002) Effects of Sodium Fluoride on Total Serum Protein Levels and Transaminase Activity in Rats. Biochemical Pharmacology, 56, 169-172. https://doi.org/10.1016/S0753-3322(02)00172-5

[35] Chattopadhyay, A., Podder, S., Agarwal, S. and Bhattacharya, S. (2011) Fluoride-Induced Histopathology and Synthesis of Stress Protein in Liver and Kidney of Mice. Archives of Toxicology, 85, 327-335. https://doi.org/10.1007/s00204-010-0588-7

[36] Vasant, R.A. and Narasimhacharya, A.V.R.L. (2012) Ameliorative Effect of Tamarind Leaf on Fluoride-Induced Metabolic Alterations. Environmental Health and Preventive Medicine, 17, 484-489. https://doi.org/10.1007/s12199-012-0277-7

[37] Ismail, H.A., Hamza, R.Z. and El-Shenawy, N.S. (2014) Potential Protective Effects of Blackberry and Quercetin on Sodium Fluoride-Induced Impaired Hepato-Renal Biomarkers, Sex Hormones and Hematotoxicity in Male Rats. Journal of Applied Life Sciences International, 1, 1-16. https://doi.org/10.9734/JALSI/2014/12057

[38] Bouasla, A., Bouasla, I., Boumendjel, A., El Feki, A. and Messarah, M. (2014) Hepatoprotective Role of Gallic Acid on Sodium Fluoride-Induced Liver Injury in Rats. International Journal of Pharmaceutical Sciences Review and Research, 29, 14-18.

[39] Kaczor, J.J., Ziolkowski, W., Popinigis, J. and Tarnopolsky, M. (2005) Anaerobic and Aerobic Enzyme Activities in Human Skeletal Muscle from Children and Adults. Pediatric Research, 57, 331-335. https://doi.org/10.1203/01.PDR.0000150799.77094.DE

[40] Heidenreich, O., Neininger, A., Schratt, G., Zinck, R., Cahill, M.A. and Engel, K. (1999) MAPKAP Kinase 2 Phosphorylates Serum Response Factor in Vitro and in Vivo. The Journal of Biological Chemistry, 274, 14434-14443. https://doi.org/10.1074/jbc.274.20.14434

[41] Kant, V., Srisvastave, A.K., Verma, P.K. and Raina, R. (2009) Alteration in Biochemical Parameters during Sub-Acute Toxicity of Fluoride Alone and in Conjunction with Aluminium Sulfate in Goats. Biological Trace Element Research, 130, 20-30. https://doi.org/10.1007/s12011-008-8311-8

[42] Giri, D.K., Ghosh, R.C., Kashyap, D.K., Dewangan, G. and Maiti, S.K. (2015) Haemato-Biochemical Alterations in Subacute Oral Toxicity of Sodium Fluoride in Wistar Rats. Journal of Animal Research, 5, 595-598. https://doi.org/10.5958/2277-940X.2015.00100.X

[43] Lu, Y., Luo, Q., Cui, H., Deng, H., Kuang, P., Liu, H., Fang, J., Zuo, Z., Deng, J., Li, Y., Wang, X. and Zhao, L. (2017) Sodium Fluoride Causes Oxidative Stress and Apoptosis in the Mouse Liver. Aging, 9, 1623-1639.

[44] Mohammed, I.A. and Al-Okaily, B.N. (2017) Effect of Sodium Fluoride on Liver Functions of Rats and Amelioration by CoQ10. Journal of Entomology and Zoology 
Studies, 5, 887-893.

[45] Yamaguti, P.Y., Simões, A., Ganzerla, E., Souza, D.N., Nogueira, F.N. and Nicolau, J. (2013) Effects of Single Exposure of Sodium Fluoride on Lipid Peroxidation and Antioxidant Enzymes in Salivary Glands of Rats. Oxidative Medicine and Cell Longevity, 2013, Article ID: 674593. https://doi.org/10.1155/2013/674593

[46] Jha, A., Shah, K. and Verma, R. (2012) Effects of Sodium Fluoride on DNA, RNA and Protein Contents in Liver of Mice and Its Amelioration by Camellia Sinensis. Acta Poloniae Pharmaceutica. Drug Research, 69, 551-555.

[47] Sauerheber, R. (2013) Physiological Conditions Affect Toxicity of Ingested Industrial Fluoride. Journal of Environmental and Public Health, 2013, Article ID: 439490. https://doi.org/10.1155/2013/439490

[48] Nehru, B. and Anand, P. (2005) Oxidative Damage Following Chronic Aluminum Exposure in Adult and Pup Rat Brains. Journal of Trace Elements in Medicine and Biology, 19, 203-208. https://doi.org/10.1016/j.jtemb.2005.09.004

[49] Yilmaza, B.O. and Erkana, M. (2015) Effect of Vitamin C on Sodium Fluoride-Induced Oxidative Damage in Sertoli Cells. Fluoride, 48, 241-251.

[50] Barbier, O., Mendoza, L.A. and DelRazo, L.M. (2010) Molecular Mechanisms of Fluoride Toxicity. Chemico-Biological Interactions, 188, 319-333. https://doi.org/10.1016/j.cbi.2010.07.011

[51] Atmaca, N., Atmaca, H.T., Kanici, A. and Anteplioglu, T. (2014) Protective Effect of Reveratol on Sodium Fluoride-Induced Oxidative Stress, Hepatotoxicity and Neurotoxicity in Rats. Food and Chemical Toxicology, 70, 191-197. https://doi.org/10.1016/j.fct.2014.05.011

[52] Shashi, A. and Thaparb, S.P. (2000) Histopathology of Fluoride-Induced Hepatotoxicity in Rabbits. Fluoride, 34, 34-42.

[53] Hamza, R.Z., El-Shenawy, N.S. and Ismail, H.A.A. (2015) Protective Effects of Blackberry and Quercetin on Sodium Fluoride-Induced Oxidative Stress and Histological Changes in the Hepatic, Renal, Testis and Brain Tissue of Male Rat. Jour nal of Basic and Clinical Physiology and Pharmacology, 26, 237-251.

[54] Bouaziz, H., Soussia, L., Guermazi, F., Zeghal, N. and Tunisia, S. (2005) Fluorideinduced Thyroid Proliferative Changes and Their Reversal in Female Mice and Their Pups. Fluoride, 38, 207-714.

[55] Samanta, A., Bandyopadhyay, B. and Das, N. (2016) Fluoride Intoxication and Possible Changes in Mitochondrial Membrane Microviscosity and Organ Histology in Rats. International Journal of Scientific Research, 5, 42-45.

[56] Ahmad, K.R., Noor, S., Jabeen, S., Nauroze, T., Kanwal, M.A., Raees, K. and Tahir, A. (2017) Amelioration by Jambul Fruit Extract of Fluoride Induced Hepato-Nephronal Histopathologies and Impaired Neuromotor Capacity in Mice. Fluoride, 50, 2-14.

[57] Halliwell, B. and Guttteridge, J.M. (2007) Free Radicals in Biology and Medicine. Oxford University Press, Clarendon, Oxford, 221-238.

[58] Anane, R. and Creppy, E.E. (2001) Lipid Peroxidation as Pathway of Aluminium Cytotoxicity in Human Skin Fibroblast Cultures: Prevention by Superoxide Dismutase + Catalase and Vitamins E and C. Human \& Experimental Toxicology, 20, 477-481. https://doi.org/10.1191/096032701682693053

[59] Chen, T., Cui, H., Cui, Y., Bai, C., Gong, T. and Peng, X. (2011) Cell-Cycle Blockage Associated with Increased Apoptotic Cells in the Thymus of Chickens Fed on Diets High in Fluorine. Human \& Experimental Toxicology, 30, 685-692. 
https://doi.org/10.1177/0960327110379022

[60] Luo, Q., Cui, H., Peng, X., Fang, J., Zuo, Z., Deng, J., Liu, J. and Deng, Y. (2013) Intestinal IgA+ Cell Numbers as Well as IgA, IgG, and IgM Contents Correlate with Mucosal Humoral Immunity of Broilers during Supplementation with High Fluorine in the Diets. Biological Trace Element Research, 154, 62-72. https://doi.org/10.1007/s12011-013-9713-9

[61] Kuang, P., Deng, H., Cui, H., Chen, L., Fang, J., Zuo, Z., Deng, J., Wang, X. and Zhao, L. (2017) Sodium Fluoride (NaF) Causes Toxic Effects on Splenic Development in Mice. Oncotarget, 8, 4703-4717. https://doi.org/10.18632/oncotarget.13971

[62] Thangapandiyan, S. and Miltonprabu, S. (2013) Epigallocatechin Gallate Effectively Ameliorates Fluoride-Induced Oxidative Stress and DNA Damage in the Liver of Rats. Canadian Journal of Physiology and Pharmacology, 91, 528-537. https://doi.org/10.1139/cjpp-2012-0347

[63] Liang, Q., Sheng, Y., Jiang, P., Ji, L., Xia, Y., Min, Y. and Wang, Z. (2011) The Gender-Dependent Difference of Liver GSH Antioxidant System in Mice and Its Influence on Isoline-Induced Liver Injury. Toxicology, 280, 61-69. https://doi.org/10.1016/j.tox.2010.11.010

[64] Chinoy, N., Sharma, A., Patel, T., Memon, R., Dd, J. and Ahmedabad (2004) Recovery from Fluoride and Aluminium Induced Free Radical Liver Toxicity in Mice. Fluoride, 37, 257-263.

[65] Kumar, A., Sharma, S.K. and Vaidyanathan, S. (1988) Results of Surgical Reconstruction in Patients with Renal Failure Owing to Ureteropelvic Junction Obstruction. Journal of Urology, 140, 484-486. https://doi.org/10.1016/S0022-5347(17)41697-1

[66] Zhan, X.A., Wang, M., Xu, Z.R. and Li, J.-X. (2006) Toxic Effects of Fluoride on Kidney Function and Histological Structure in Young Pigs. Fluoride, 39, 22-26.

[67] Al-Harbi, M.S., Hamza, R.Z. and Dwari, A.A. (2014) Sodium Fluoride Induced Antioxidant Defense Impairment and Impaired Renal Biomarkers and the Ameliorative Role of Selenium and Curcumin in Male Mice. Asian Pacific Journal of Tropical Disease, 4, S990-S997. https://doi.org/10.1016/S2222-1808(14)60771-4

[68] Shashi, A., Singh, J.P. and Thapar, S.P. (2002) Toxic Effects of Fluoride on Rabbit Kidney. Fluoride, 35, 38-50.

[69] Poesina, N.D., Balalau, C., Nimigean, V.R., Nimigean, V., Ion, I., Baconi, D. and Poesina, V.B. (2014) Histopathological Changes of Renal Tissue Following Sodium Fluoride Administration in Two Consecutive Generations of Mice. Correlation with the Urinary Elimination of Fluoride. Romanian Journal of Morphology and Embryology, 55, 343-349.

[70] Shashi, A. and Kaur, J. (2017) Attenuation of Fluoride-Induced Nephrotoxicity in Rats by Leaf Extract of Punarnava (Boerhaavia diffusa L.). European Academic Research, 5, 3805-3822.

[71] Shimizu, S., Eguchi, Y., Kamiike, W., Waguri, S., Uchiyama, Y., Matsuda, H. and Tsujimoto, Y. (1996) Retardation of Chemical Hypoxiainduced Necrotic Cell Death by Bcl-2 and ICE Inhibitors: Possible Involvement of Common Mediators in Apoptotic and Necrotic Signal Transductions. Oncogene, 12, 2045-2050.

[72] Chagnac, A., Weinstein, T., Korzets, A., Ramadan, E. and Hirsch, J. (2000) Glomerular Hemodynamics in Severe Obesity. American Journal of Physiology-Renal Physiology, 278, F817-F822. https://doi.org/10.1152/ajprenal.2000.278.5.F817

[73] Chen, H.M., Liu, Z.H., Zeng, C.H., Li, S.J., Wang, Q.W. and Li, L.S. (2006) Podocyte 
Lesions in Patients with Obesity-Related Glomerulopathy. American Journal of Kidney Diseases, 48, 772-779. https://doi.org/10.1053/j.ajkd.2006.07.025

[74] Salam, Z. and Agha, A. (2007) Histological, Histochemical and Ultrastructural Studies on the Kidney of Rats after Administration of Monosodium Glutamate. Al-Aqsa University, Gaza, 21-40.

[75] Inkielewicz-Stepniak, I. and Knap, N. (2012) Effect of Exposure to Fluoride and Acetaminophen on Oxidative/Nitrosative Status of Liver and Kidney in Male and Female Rats. Pharmacological Reports, 64, 902-911. https://doi.org/10.1016/S1734-1140(12)70885-X

[76] Bharti, V.K., Srivastava, R.S., Kumar, H., Bag, S., Majumdar, A.C., Singh, G., Pandi-Perumal, S.R. and Brown, G.M. (2014) Effects of Melatonin and Epiphyseal Proteins on Fluoride-Induced Adverse Changes in Antioxidant Status of Heart, Liver, and Kidney of Rats. Advances in Pharmacological Sciences, 2014, Article ID: 532969. https://www.hindawi.com/journals/aps/2014/532969 https://doi.org/10.1155/2014/532969

[77] Song, Y., Wang, J.C., Xu, H., Du, Z.W., Zhang, G.Z., Selim, H.A., Li, G.S., Wang, Q. and Gao, Z.L. (2013) Fluorosis Caused Cellular Apoptosis and Oxidative Stress of Rat Kidneys. Chemical Research in Chinese Universities, 29, 263-269. https://doi.org/10.1007/s40242-013-2430-2

[78] Song, G.H., Gao, J.P., Wang, C.F., Chen, C.Y., Yan, X.Y., Guo, M., Wang, Y. and Huang, F.B. (2014) Sodium Fluoride Induces Apoptosis in the Kidney of Rats through Caspase-Mediated Pathways and DNA Damage. Journal of Physiology and Biochemistry, 70, 857-868. https://doi.org/10.1007/s13105-014-0354-Z

[79] Bano, M. and Bhatt, D.K. (2007) Neuroprotective Role of a Novel Combination of Certain Antioxidants on Lindane $(\gamma-\mathrm{HCH})$ Induced Toxicity in Cerebrum of Mice. Research Journal of Agriculture and Biological Sciences, 3, 664-669.

[80] Garcia-Montalvo, E.A., Reyes-Perez, H. and Del Razo, L.M. (2009) Fluoride Exposure Impairs Glucose Tolerance via Decreased Insulin Expression and Oxidative Stress. Toxicology, 263, 75-83. https://doi.org/10.1016/j.tox.2009.06.008

\section{List of Abbreviations}

ACP: acid phosphatase, ALT: alanine amino-transferase, ALP: alkaline phosphatase, AST: aspartate aminotransferase, CAT: catalase, F: fluoride, FADD: Fas-associated death domain, GGT or $\gamma$-GT: gamma-glutamyl transferase, GPx: glutathione peroxidase, GSH: glutathione level, GST: glutathione-s-transferase, HDL-C: high-density lipoprotein cholesterol, LDH; lactate dehydrogenase, LPO: lipid peroxidation, MDA: malondialdehyde, 8-OHdG: 8-Hydroxy-2'-deoxyguanosine, SOD2: manganese superoxide dismutase, PGE2: prostaglandin E2, ROS: reactive oxygen species, SOD: superoxide dismutase, TBIL: total bilirubin, TNF-R1: tumor necrosis factor receptor-1, TRADD: TNFR-associated death domain. 